\title{
Bacterial Vaginosis: A Risk Factor for Preterm Labour- A Case - Control Study
}

\author{
Authors
}

\author{
Dr Shazia Iqbal $^{1}$, Dr Soma Bandyopadhyay ${ }^{2}$, Dr Poonam Kumari ${ }^{3}$ \\ ${ }^{1}$ PGT $2{ }^{\text {nd }}$ year, Dept. of Obstetrics \& Gynaecology, KMCH \\ ${ }^{2}$ Professor, Dept of Obstetrics \& Gynaecology, KMCH \\ ${ }^{3}$ PGT $2^{\text {nd }}$ year, Dept. of Obstetrics \& Gynaecology, $\mathrm{KMCH}$
}

\begin{abstract}
Aim: To estimate the prevalence of Bacterial Vaginosis in preterm labour cases as compared to term labour.

Pre-term birth is the single most important factor of adverse neonatal outcome.

Materials \& Methods: In this study, 100 patients admitted in Obs \& Gynae. ward of KMCH for period July-January 2018 with true labour pain were taken and segregated into cases \& controls after taking their consent:

Group 1(Case)- 50 patients preterm labour at $>28$ to $\leq 36^{\wedge}+6$ wks. $P O G$

Group2(Control)- 50 term labour patients at $\geq 37$ wks $P O G$

Speculum examination was done for both \& evaluated. Smear from posterior fornix was taken using swabs under wet mount, $\mathrm{KOH}$ (whiff test).

Diagnosis is made if 3 out of 4 AMSEL'S Criteria is found true:

Homogenous vaginal discharge

Vaginal $\mathrm{pH}>4.5$

Positive whiff test

Presence of clue cells $>20 \%$

Result: Among the 50 cases \& 50 controls studied, bacterial vaginosis was present in 15 preterm labour patients (CASE) \& 3 term labour patients (Control).

Thus, women with bacterial vaginosis have increased risk of pre-term labour.

Conclusion: Bacterial Vaginosis is a common but poorly understood clinical syndrome wherein for some unknown reason, the vaginal flora shifts \& anaerobic species overgrow.

Thus, our study concludes that bacterial vaginosis is one of the most important causes of pre-term labour. Routine screening and treatment of bacterial vaginosis will thus help reduce Preterm labour incidence \& further reduce perinatal morbidity and mortality.
\end{abstract}

\section{Introduction}

Among the multiple causes of perinatal mortality and morbidity the greatest cause is pre-term labour. Pre-term birth is delivery before 37 weeks.
Vaginal infection plays a key role in pre-term birth, which is especially true in bacterial vaginosis. Bacterial vaginosis accounts for at least $1 / 3$ of all vulvovaginal infections. Common 
Agents of bacterial vaginosis are gardnerella vaginalis, mobilincus and ureaplasma urealyticum. The pathogenesis of bacterial vaginosis is explained by replacement of normal vaginal flora by anaerobic bacteria. The products of these bacteria stimulate the decidua's and cause pre-term labour. Vaginal discharge is the most common complaint. Infection of bacterial vaginosis during pregnancy is associated with many complications like Chorioamnionitis, preterm birth, Low birth weight, pre-mature rupture of membrane and fetal loss.

\section{Aims and Objective}

To Study the prevalence of Bacterial Vaginosis in women presenting with pre-term labour when compared to term labour and Analyse relationship between bacterial vaginosis and pre-term labour.

\section{Materials and Methods}

It is a hospital based prospective case-control study conducted in Department of Obs and Gynae in Katihar Medical College over a period from July 2018 - January 2019. In this study 100 patients having true labour pains were admitted as case and control. The study was approved by the institutional ethical committee and informed consent was taken from all the cases and controls in the study. A case record of clinical history gestational age at delivery, new born birth weight and condition were noted.

\section{Group 1 (Case Selection)}

50 pre-term labour patients with period of gestation $\geq 28$ wks.till $\leq 36^{+6}$ wks. were admitted.

\section{Group 2 (Control Selection)}

50 term labour patients with period of gestation $\geq$ 37 wks. were admitted.

\section{Exclusion Criteria}

- Women $\leq 18$ yrs $\geq 35$ yrs

- H/O Prev PROM

- Multiple Pregnancy

- Placenta Previa/Abruptio

- Uterine Anomalies

- $\mathrm{PIH}$

- DM

\section{Specimen Collection + Processing}

Speculum examination was done for both case + control and evaluated for any abnormal vaginal discharge and vaginal $\mathrm{pH}$. Smear from post fornix was taken using sterile swabs for wet mount, $\mathrm{KOH}$ (whiff test). Diagnosis was mad if 3 of 4 Amsel's criteria was found.

Table:- 1 Amsel's Criteria for Diagnosis of BV: Three of the following four criteria must be met. Establishes accurate diagnosis of bacterial vaginosis in $90 \%$ of affected women

\begin{tabular}{|ll|}
\hline 1. & $\begin{array}{l}\text { Homogeneous, non-clumping vaginal discharge } \\
\text { (colour and amount may vary) }\end{array}$ \\
\hline 2. & $\begin{array}{l}\text { Amine (fishy) odour when potassium hydroxide } \\
\text { solution is added to vaginal secretions (commonly } \\
\text { called the "whiff test") }\end{array}$ \\
\hline 3. & $\begin{array}{l}\text { Presence of clue cells (greater than 20\%) on } \\
\text { microscopy }\end{array}$ \\
\hline 4. & Vaginal pH greater than 4.5 \\
\hline
\end{tabular}

\section{Result}

As per our study all 50 cases and 50 controls were studied. Among them bacterial vaginosis was present in $15(30 \%)$ of pre-term labour patients and $3(6 \%)$ of term labour patients.

Table: 2 Prevalence of Bacterial Vaginosis

\begin{tabular}{|l|c|c|}
\hline & Present & Absent \\
\hline Case (Pre-Term) N=50 & $15(30 \%)$ & $35(70 \%)$ \\
\hline Control (Term) N=50 & $3(6 \%)$ & $47(94 \%)$ \\
\hline
\end{tabular}

Table: 3 Fetal outcome in Bacterial Vaginosis patients

\begin{tabular}{|l|c|c|}
\hline & $\begin{array}{c}\text { Pre-Term Labour BV } \\
\text { N=15 }\end{array}$ & $\begin{array}{c}\text { Term Labour BV } \\
\text { N=3 }\end{array}$ \\
\hline LBW & 7 & 1 \\
\hline NBW & 5 & 2 \\
\hline $\begin{array}{l}\text { Neonatal } \\
\text { Complication }\end{array}$ & 3 & 0 \\
\hline
\end{tabular}

\section{Discussion}

The Casual relationship between vaginal microflora and spontaneous pre-term birth has gained lot of importance. Most of these cases during pregnancy get unnoticed until screened. In pregnant women bacterial vaginosis prevalence was ranging from 6 to $30 \%$.

In present study bacterial vaginosis is found to be more common in pre-term labour patients $(30 \%)$ when compared to term labour patients $(6 \%)$. Which is statistically significant. 
Risk Estimate

Table: - 4 Odds ratio

\begin{tabular}{|l|c|c|}
\hline & Present & Absent \\
\hline Case & 15 & 35 \\
\hline Control & 3 & 47 \\
\hline
\end{tabular}

$=6.714$

$\underline{\text { Relative Risk }=}=\frac{\text { Incicence exposed }}{\text { Incidence } \text { Non exposed }}=\mathbf{1 . 9 5 2}$ Both values signify $>1+$ relation

Thus, women with bacterial Vaginosis has increased risk of pre-term labour when compared to patients without bacterial vaginosis.

\section{Conclusion}

The present study clearly demonstrates significant association of pre-term labour with bacterial vaginosis. Therefore, screening of bacterial vaginosis as a routine during pregnancy and its prompt treatment may reduce the risk of pre-term labour. This will also go a long way in prevention of neonatal complication due to pre-maturity.

\section{References}

1. McCormick MC. The contribution of low birth weight to infant mortality and childhood morbidity. N Engl J Med. 1985; 312:82-90.

2. Romero R, Mazor M. Infection and preterm labor. Clin Obstet Gynecol. 1988; 31:553-84.

3. Guaschino S, De Seta F, Piccoli M, Maso G, Alberico S. Aetiology of preterm labour: bacterial vaginosis. BJOG. 2006;113(Suppl 3):46-51.

4. Donders GG, Van Bulck B, Caudron J, Londers L, Vereecken A, Spitz B. Relationship of bacterial vaginosis and mycoplasmas to the risk of spontaneous abortion. Am J Obstet Gynecol. 2000; 183:431-7.

5. Lamont RF, Anthony F, Myatt L, Booth L, Furr PM, Taylor-Robinson D. Production of prostaglandin E2 by human amnion in vitro in response to addition of media conditioned by microorganisms associated with chorioamnionitis and preterm labor. Am J Obstet Gynecol. 1990; 162:819-25.

6. American College of Obstetricians and Gynecologists. Assessment of risk factors for preterm birth. Clinical management guidelines for obstetrician-gynecologists. ACOG Practice Bulletin. J Obstet Gynecol. 2001;98(4):709-16.

7. Priestley CJ, Jones BM, Dhar J, Goodwin L. What is normal vaginal flora? Genitourin Med. 1997; 73:23-8.

8. Hillier SL. Diagnostic microbiology of bacterial vaginosis. Am J Obstet Gynecol. 1993; 169:455-9.

9. Newton ER, Piper J, Peairs W. Bacterial vaginosis and intraamniotic infection. Am J Obstet Gynecol. 1997; 176:672-7.

10. Chawanpaiboon S, Pimol K. Bacterial vaginosis in threatened preterm, preterm and term labour. J Med Assoc Thai. 2010;93(12):1351-5. 